\title{
1 Growth allometry and dental topography in Upper Triassic 2 conodonts supports trophic differentiation and molar-like 3 element function
}

4

\author{
Valentin Kelz ${ }^{1}$, Pauline Guenser ${ }^{1}$, Michele Mazza $^{2}$, Manuel Rigo ${ }^{3}$, Emilia Jarochowska ${ }^{1}$ \\ ${ }^{1}$ Fachgruppe Paläoumwelt, GeoZentrum Nordbayern, Friedrich-Alexander-Universität \\ Erlangen-Nürnberg, Erlangen, Germany \\ ${ }^{2}$ Largo Mazza, 29121, Piacenza, Italy \\ ${ }^{3}$ Department of Geosciences, University of Padova, Padova, Italy
}

Corresponding Author:

Pauline Guenser ${ }^{1}$

Fachgruppe Paläoumwelt, GeoZentrum Nordbayern, Friedrich-Alexander-Universität ErlangenNürnberg, Loewenichstr. 28, 91054 Erlangen, Germany

Email address: pauline.guenser@gmail.com

\section{Abstract}

Conodont dental elements are distinguished by their high disparity and rapid morphological evolution. $\mathrm{P}_{1}$ elements located in the pharynx are the most rapidly evolving, but their function in the animal has been only investigated in a handful of taxa and proposed to be analogous to mammal molars. This hypothesis predicts that their surface area should show positive allometry with respect to element length, as has been previously identified in 2D projections in two Carboniferous taxa. Here we apply the same method to test this hypothesis in 3D models of platform-bearing $\mathrm{P}_{1}$ elements of two common Late Triassic taxa, Metapolygnathus communisti and Epigondolella rigoi. We further hypothesise that these commonly co-occurring taxa differed in their growth allometry, reflecting their different trophic niches. Platform length grew isometrically with respect to element length, whereas log-transformed platform area showed positive allometry with respect to element length, with slopes equal 3.86 in M. communisti and 4.16 in E. rigoi, supporting a function of the platform analogous to molars and trophic differentiation. We cross-tested the latter interpretation by dental topographic analysis using Dirichlet Normal Energy (DNE). Specimens of the adult growth stage of E. rigoi showed higher DNE values than specimens of the same growth stage in $M$. communisti, consistent with stronger positive allometry of platform surface and with a higher demand for energy in this species. DNE values of platform surface increased linearly in function of element length and logtransformed platform area, indicating no ontogenetic changes. Based on DNE values available for primates, those of the adult growth stages were similar to those reported for insectivores or folivores in the case of E. rigoi and for folivores or omnivores in the case of M. communisti.
\end{abstract}


Previous studies applying morphological and ultrastructural proxies for the dietary position of conodonts addressed mostly stratigraphically older conodont taxa, but our results indicate that Late Triassic species occupied the predator/scavenger niche in spite of the highly developed diversity of gnathostomes in this niche. We also show that within this broad niche, co-occurring taxa differed in their diets, which supports trophic diversification as an important driver of the remarkable disparity of their elements.

\section{Introduction}

48 Conodonts are extinct, eel-shaped marine animals that lived from the middle Cambrian to Early Jurassic (Du et al., 2020). They are early vertebrates (Donoghue, Purnell \& Aldridge, 1998) distinguished by an extensive fossil record (Foote \& Sepkoski, 1999; Donoghue, 2001a). The majority of conodont fossil record consists of the phosphatic elements forming the feeding apparatus of the animal (Scott, 1934; Schmidt, 1934; Purnell, Donoghue \& Aldridge, 2000). Soft tissues are rarely found and have, so far, not revealed a great diversity of body forms. Because of this, conodont taxonomy and functional morphology are based on their elements (Mazza, Cau \& Rigo, 2012).

\section{Evidence of dental function}

Several lines of argumentation have been proposed to argue that elements of the conodont feeding apparatus had a tooth-like function. $\mathrm{S}$ and $\mathrm{M}$ elements, positioned in the anterior part, i.e. the mouth, are interpreted to perform a grasping function, whereas $\mathrm{P}$ elements, placed in the posterior part of the apparatus in the pharynx of the animal, have been proposed to have a function similar to molars of mammals(Purnell \& von Bitter, 1992; Purnell, 1994; Donoghue \& Purnell, 1999a). A model of conodonts being suspension feeders has also been suggested (Nicoll, 1987). In this model, elements would be covered in tissue and $S$ and $M$ elements would filter particles and create current. $\mathrm{P}_{1}$ elements would only lightly mash food. This model, however, is not supported by more recent research.

Following arguments have been proposed for the dental function of conodont elements: (1) the presence of microwear patterns on conodont elements, produced in vivo (Purnell, 1995; Martínez-Pérez et al., 2014c); (2) occlusion models (Donoghue \& Purnell, 1999a; Jones et al., 2012a; Martínez-Pérez et al., 2014c,b); (3) Finite Element Analysis (FEA) (Jones et al., 2012b; Martínez-Pérez et al., 2014c, 2016); (4) ultrastructural adaptation of conodont tissues to dental function, analogous to enamel (Donoghue, 2001b; Jones et al., 2012a); (5) in some conodont taxa, extreme sharpness has been proposed to be an adaptation to cutting function in the absence of jaws acting as levers (Jones et al., 2012b); and the last argument, examined here, (6) growth

75 allometry (Purnell, 1993, 1994). 


\section{Trophic level of conodonts}

Patterns interpreted to by produced by shearing on the surface and repaired during the animal's growth suggest macrophagy (Purnell, 1995; Donoghue \& Purnell, 1999b; Shirley et al., 2018). An active, predatory lifestyle is supported by the discovery of a conodont specimen with preserved extrinsic eye musculature (Gabbott, Aldridge \& Theron, 1995), which was interpreted as indicative of conodonts having pattern vision (Purnell, 1994). Calcium isotope analyses indicated that Triassic conodonts were first-level zooplanktivore and piscivore consumers (Balter et al., 2019), suggesting that in this Period, conodonts did not lead a purely predatory lifestyle, but rather were first level consumers. The study suggested that Triassic conodonts may have been scavengers of small fish.

\section{Changes in the function of conodont elements during ontogeny}

Conodont elements were retained throughout the life of an individual (Donoghue \& Purnell, 1999b), recording periodic growth through apposition of crown tissue lamellae (Zhang, Aldridge \& Donoghue, 1997; Dzik, 2008). Shirley et al. (2018) suggested that tooth-like function in conodont elements may have only developed after a larval stage, during which they exhibited a different feeding habit, as mechanical wear of conodont elements is only present after a certain stage of ontogenetic development. After this stage, elements appear to have had prolonged intervals of dental use and short intervals of growth, during which conodonts did not feed and their elements were covered in soft tissue, depositing new layers (Bengtson, 1976; Donoghue \& Purnell, 1999b; Shirley et al., 2018).

\section{Open questions}

Conodonts changed their apparatus structure and disparity across their stratigraphic range (Dzik, 1991, 2015), possibly reflecting their evolving niches as marine ecosystems increased in complexity (Klug et al., 2010; Ginot \& Goudemand, 2019). Their morphology also diversified (Martínez-Pérez et al., 2014a, 2015; Ginot \& Goudemand, 2020). This would suggest evolving trophic niches under the assumption that conodont element morphology is an adaptation to their diet (Jones et al., 2012a; Guenser et al., 2019; Ginot \& Goudemand, 2019; Petryshen et al., 2020). There is, however, evidence from $\mathrm{Ca}$ isotope analysis, suggesting the existence of competition between some taxa, which indicates that trophic niches overlapped between them (Balter et al., 2019). Since no direct evidence of what individual taxa ate could be obtained so far, trophic diversity of conodonts must be inferred from proxies, e.g. by evaluating morphological and functional diversity of food-processing elements. Here we use growth allometry, first applied to conodonts by Purnell $(1993,1994)$, as a proxy for the dental function.

\section{Allometry}

Allometry describes proportional relationships in bodies, usually the size of an organ to the total size of the organism. Its use has become popular during the paleontological revolution (Gould, 1966; Alberch et al., 1979) and has since become a popular tool in different fields of biology and 
palaeontology. Allometric relationships can be explored at different scales. Static or size allometry describes variation among individuals of one population and age group. Ontogenetic or growth allometry describes variation in one taxon, as individuals of the taxon grow. Evolutionary allometry describes the variation between taxa, resulting from evolutionary development (Klingenberg, 1996). Proportional growth, meaning, for example, growth of an organ and growth of the size of the animal at the same rate is called isometry. Positive allometry then describes the organ growing at a higher rate than the rest of the animal. An example of this are the long bones of limbs in humans. Negative allometry, conversely, describes the organ growing at a lower rate than the rest of the body. An example for this is the development of head height (Gould, 1966; Alberch et al., 1979; Klingenberg, 1996). For conodonts, this means that if conodont elements had a tooth-like function, and specifically, if $\mathrm{P}_{1}$ elements were used like molars, positive ontogenetic allometric growth of the elements platform to the animal's size can be expected and has been described in Idiognathodus sp. and Gnathodus bilineatus (Purnell, 1993, 1994). This is because tooth function is linked to surface area and because food requirements of an animal increase at a higher rate than an isometrically growing tooth (Gould, 1966).

\section{Dirichlet Normal Energy} analysed with methods designed for teeth to infer the diet of the organism. One such method is The Dirichlet Normal Energy (DNE), a dental topographic analysis that is a measure for the curvature and morphological irregularity of a surface. Essentially, DNE is a measure of how much a given surface differs from a plane (Bunn et al., 2011). Surface topography is an important feature of teeth because they help in breaking down food and can be used to infer diet (Bunn et al., 2011). analyse the teeth of mammals, and primates in particular (Bunn et al., 2011; Winchester et al., 2014).

\section{Aim of the study}

In this work, we address the question, originally proposed by Purnell (1993), that conodont $\mathrm{P}_{1}$ elements performed molar-like function and that this is reflected in the growth allometry of their surface versus length. The null hypothesis is that this relationship is isometric, what would be expected in filter feeders. In contrast to Purnell's (1993) study, which used projections of the surface on a plane, we use 3D meshes to calculate a more accurate platform area than is possible with a two dimensional approximation.

We further test the hypothesis that conodonts occupying the same environments had the same trophic position. To reject this hypothesis, slopes of the growth allometry of $\mathrm{P}_{1}$ element surface versus length should differ. 
Under the assumption that that $\mathrm{P}_{1}$ platforms performed a molar-like function, we further

hypothesise that (1) the diets of studied species did not change during ontogenetic growth of one species and that (2) their diets did not differ between species that lived in similar environments. This is tested using Dirichlet Normal Energy (DNE) of the platforms of the elements, as platforms are parts of elements that vary most prominently between elements and thus are inferred to reflect differences in their trophic positions (Jones et al., 2012b; Martínez-Pérez et al., 2016).

Under the null hypothesis (1), DNE values are expected to increase linearly with conodont size. Deviations from a linear relationship would suggest that diets changed across growth stages, allowing us to reject the hypothesis. Under the null hypothesis (2), DNE values of the two species are expected to be the same. Indistinguishable (overlapping) distributions of DNE values of one growth stage between the two species would falsify the hypothesis, indicating no difference in diet. Hayashi, 1968 (Hayashi, 1968) and Epigondolella rigoi (Noyan \& Kozur, 2007) which often cooccur in the same assemblages.

\section{5}

\section{Materials \& Methods}

\section{Geological location}

We used 3D surfaces of $\mathrm{P}_{1}$ elements of the ozarkodinid conodont species Metapolygnathus communisti and Epigondolella rigoi from Pizzo Mondello in western Sicily, Italy, where they were collected from a section of $430 \mathrm{~m}$ thick marine limestone that is dated to the upper Carnian to upper Norian (Mazza, Rigo \& Gullo, 2012). These specimens have an average CAI (colour alteration index) of 1-1.5 which suggests minimal post depositional heating (Epstein, Epstein \& Harris, 1977; Nicora et al., 2007; Mazza, Rigo \& Gullo, 2012).

\section{Repository}

The studied elements are housed in the collection of the Dipartimento di Scienze della Terra "A. Desio" of the Università degli Studi di Milano. Conodont collection of Pizzo Mondello section is housed in Milan and in Padova (Department of Geosciences, University of Padova).

\section{Micro CT-scanning}

The 3D surfaces were produced through micro CT-scanning. The elements were scanned with a resolution of $1 \mu \mathrm{m}$ with a microtomograph nanotomS (General Electric) of the AniRA-ImmOs platform, SFR Biosciences (UMS 3444), Ecole Normale Superiéure de Lyon, France. Amira@ software was used for the 3D reconstruction (Guenser et al., 2019).

\section{Identification of growth stages}

The most complete specimens have been selected for 3D scanning (Guenser et al., 2019; Figure 1-Figure 2). $P_{1}$ elements were separated into six growth stages (GS) based on the maturity of morphological characters of the platform (Mazza \& Martínez-Pérez, 2015). The six growth 
bioRxiv preprint doi: https://doi.org/10.1101/2021.06.10.447946; this version posted June 10, 2021. The copyright holder for this preprint (which was not certified by peer review) is the author/funder. All rights reserved. No reuse allowed without permission.

197 stages are GS1 - early juvenile, GS2 - juvenile, GS3 - late juvenile, GS4 - early adult, GS5 198 adult and GS6 - late adult (Mazza \& Martínez-Pérez, 2015).

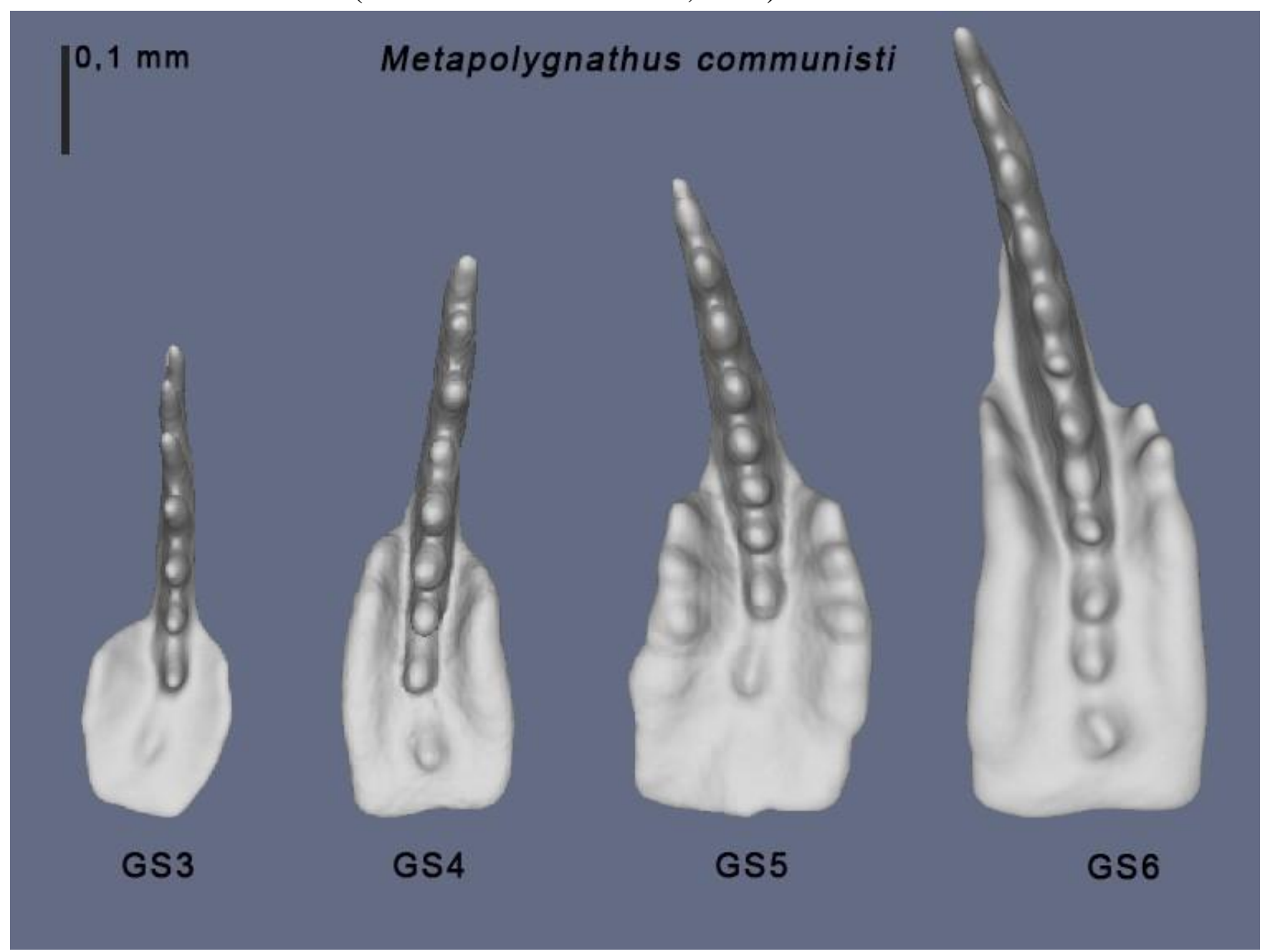




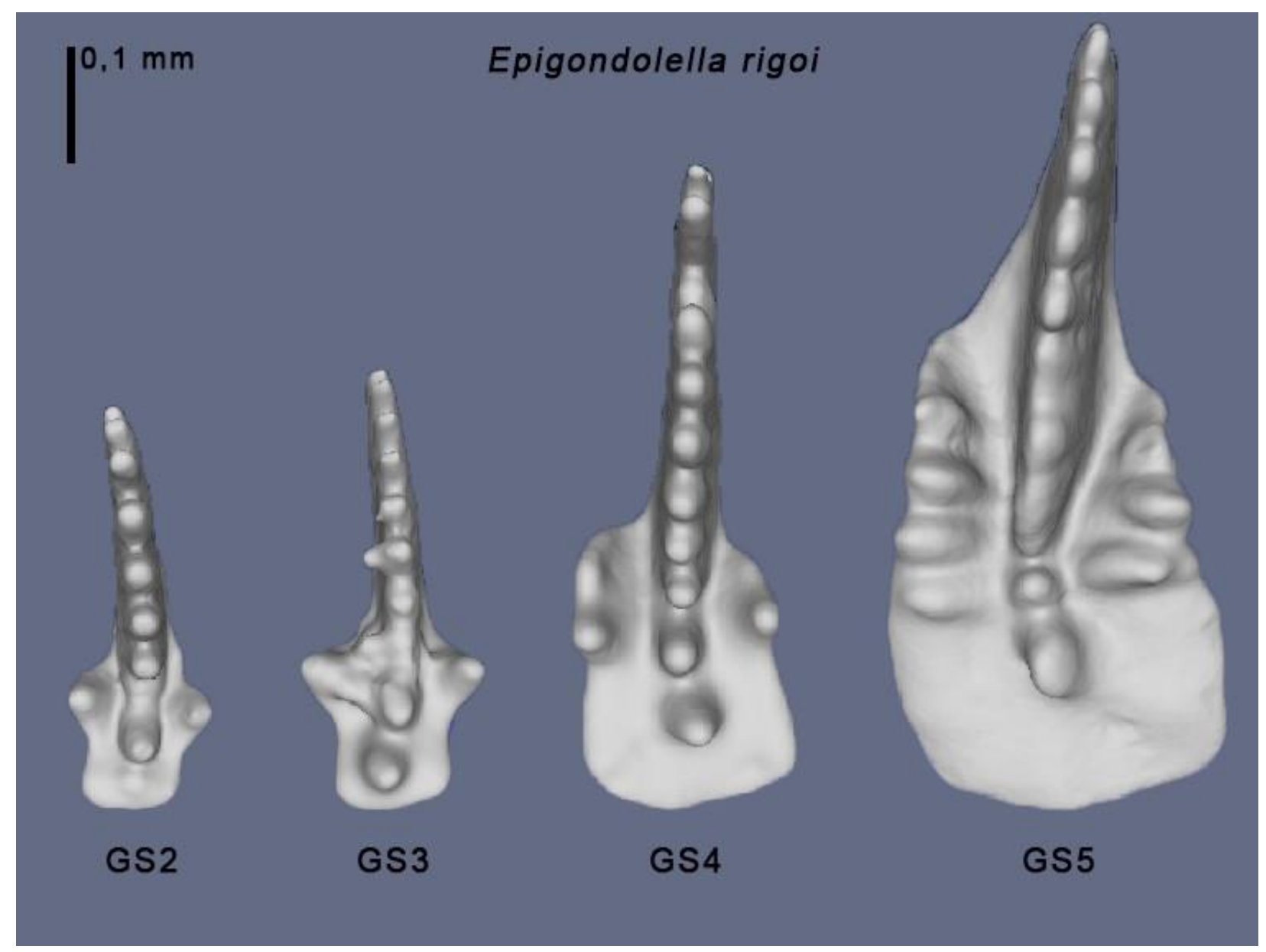

Figure 2: Growth stages of Epigondolella rigoi

203 Growth stage 1 (early juvenile) is characterised by only a simple blade with three to five denticles and a cusp and a rounded or elongated basal cavity being present. By growth stage 2 (juvenile), elements have developed four to seven blade denticles, a very reduced lateral platform margin and a deep pit. Their size does not vary much from GS1. Growth stage 3 (late juvenile) shows six to nine blade denticles that begin to merge in the middle, the formation of a reduced platform with nodes or denticles on the platform margins not present or at least not fully developed. The pit gets shallower while the posterior kneel starts to develop. Growth stage 4 (early adult) is characterised by nine to ten almost fused blade denticles, a developed platform with ornamentation (nodes or denticles on the platform margin) still not fully developed, a narrow and shallow pit and the starting bifurcation of the kneel, if a bifurcated kneel is present in that species. By growth stage 5 (adult), all important characters of a species are present.

214 Elements show ten to thirteen blade denticles that are now completely fused and platform 215 ornamentation is fully developed. Growth stage 6 (late adult) shows an increase in growth 216 compared to GS5 (10-20\%), and an overdevelopment of characteristics, such as thickening of 217 platform margins, further fusing of blade and platform denticles and the closing of the pit (Mazza 218 \& Martínez-Pérez, 2015). 
219 Twenty-seven $\mathrm{P}_{1}$ elements of Metapolygnathus communisti were used. At Pizzo Mondello, this 220 species occurs from the upper Carnian to the lower Norian (Mazza, Nicora \& Rigo, 2018). The 221 specimens range from late juvenile to late adult (GS3-GS6), though mature elements are more 222 abundant (Table 1).

223 Twenty-three $\mathrm{P}_{1}$ elements of Epigondolella rigoi were used. The stratigraphic range of this 224 species at Pizzo Mondello is from the lower Norian to the middle Norian (Mazza et al., 2010), a 225 significantly longer interval than Metapolygnathus communisti. Elements range from GS2 to 226 GS5, again, earlier ontogenetic stages are sparse (Table 1).

Table 1: Numbers of conodont $\mathrm{P}_{1}$ element specimens by growth stages used for the study.

\begin{tabular}{lll} 
& Metapolygnathus communisti & Epigondolella rigoi \\
\hline GS2 & 0 & 1 \\
GS3 & 3 & 1 \\
GS4 & 2 & 6 \\
GS5 & 7 & 15 \\
GS6 & 15 & 0
\end{tabular}

\section{9}

\section{Methods}

\section{Growth allometry}

232 The length of the element was used as a proxy for the size of the conodont animal, as has been 233 done in previous studies (Purnell, 1993, 1994; Zhang et al., 2018; Ginot \& Goudemand, 2019). 234 The length of the element, as well as the length and the area of the platform, were measured 235 using the 3D software MeshLab (Cignoni et al., 2008). The length of the element was measured 236 from the anteriormost point of the blade in a straight line to the middle of the edge of the 237 element's platform.

238 As the platform is not equally long on the two sides of the blade, its length was measured in 239 different ways. First, as most elements are curved, the convex side of the platform was measured.

240 In Metapolygnathus communisti this tended to be, though not always, the longer side of the 241 platform. In Epigondolella rigoi this was almost exclusively also the longer side. As a second 242 way of measuring, the longer side of the platform was measured, regardless of curvature (Figure $2433)$. 


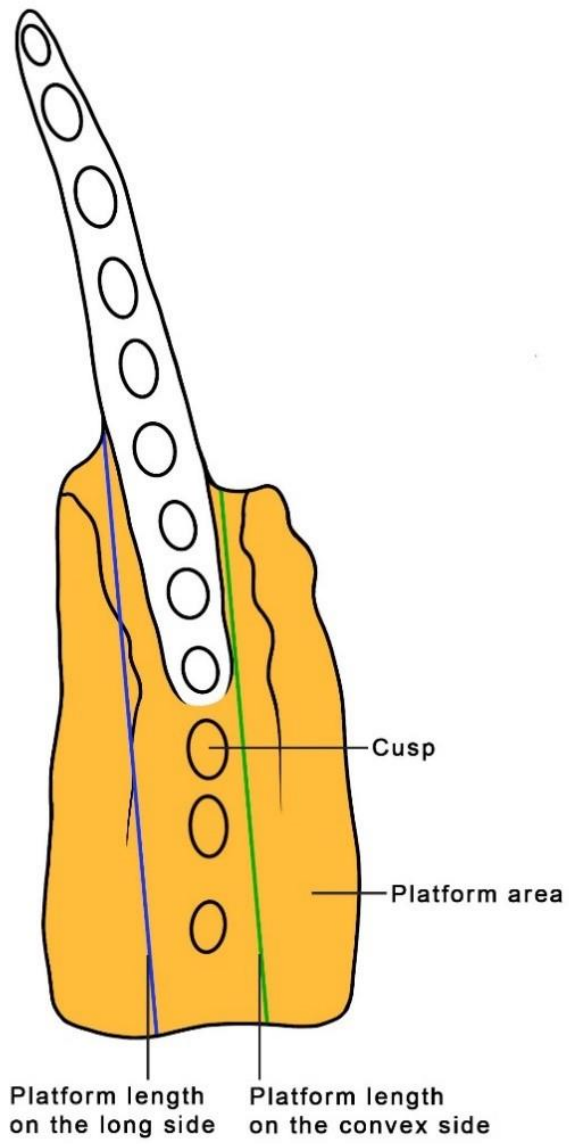

245 Figure 3: Measurements of $\mathrm{P}_{1}$ elements. In most cases one the convex side is also the long side.

246 In M. communisti, in both instances, the platform was measured from the most anterior part of 247 the platform to its posterior end in a line parallel to the imagined symmetrical axis of the 248 platform (Figure 3).

249 In E. rigoi, the platform was measured from the geniculation point to the platform's posterior 250 end, as the anterior through margin in this species, though reduced (Mazza, Cau \& Rigo, 2012) 251 reaches quite far up the blade, especially in more mature growth stages (Figure 4). 


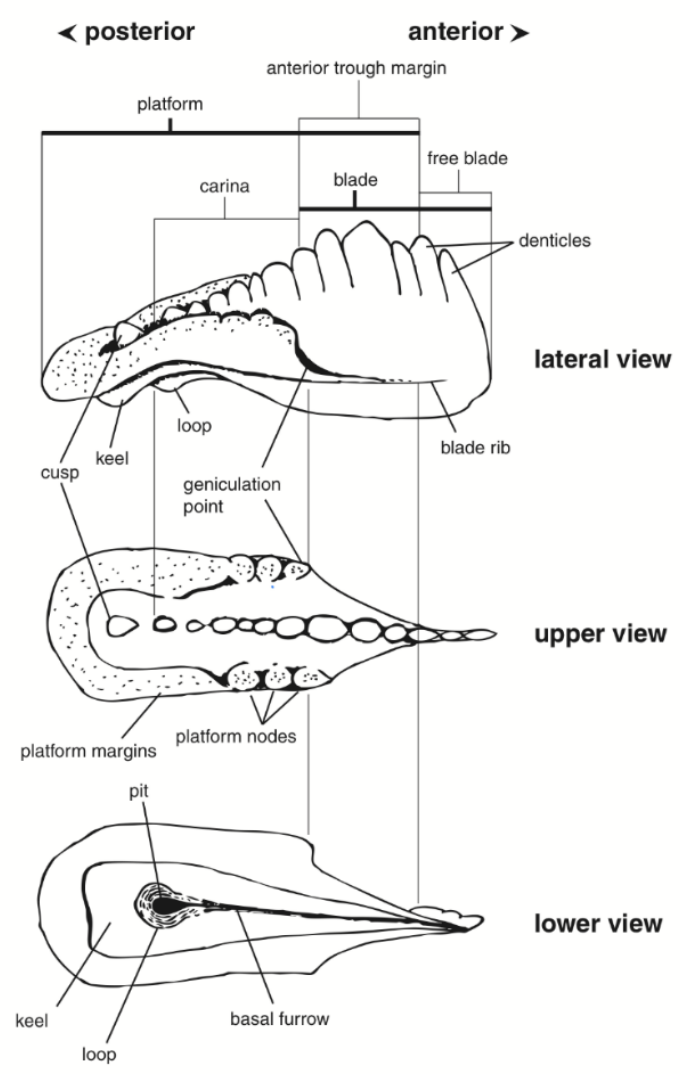

Figure 4: Morphological and structural terms used in the description of $\mathrm{P}_{1}$ elements from Mazza, Cau \& Rigo (2012)

The measured area of the platform includes the platform itself and additionally the cusp and any carinal nodes that follow the cusp on its posterior side (Figure 3).

In $M$. communisti, specimens of earlier growth stages tend to exhibit only one posterior carinal node, which is already present in GS1. From GS3 on, a second posterior node may appear (Mazza \& Martínez-Pérez, 2015). Adult specimens show 3-4 posterior carinal nodes (Mazza, Rigo \& Gullo, 2012). In our measurements, however, we found that we consistently identified only 2-3 posterior carinal nodes in adult specimens. In E. rigoi the cusp is always the second to last denticle on the carina, followed on its posterior side by a single larger node (Mazza, Rigo \& Gullo, 2012). These parts of $\mathrm{P}_{1}$ elements were added to the measurements of the platform area, even though they are taxonomically not part of the platform, because they likely played a similar part in the processing of food as the platform itself. In E. rigoi, the anterior through margin was not included in the measurements of the platform area. The anterior trough margin is not present in M. communisti (Mazza, Rigo \& Gullo, 2012). Mean, median and variance of lengths and areas of the $\mathrm{P}_{1}$ elements were calculated for each growth stage with R Software (R Core Team, 2021). Reduced major axis regression (RMA) was calculated using the R package "smatr" (Warton et al., 2012) to examine the relationship between the length of the platform and the length of the element, as well as the logarithm of the platform area and the length of the elements. The 
272 platform area was log-transformed to account for its increase as a square of the length of the

DNE

Dirichlet Normal Energy (DNE) measures a surface's curvature and complexity. The DNE of an object is independent of its size and orientation. The DNE equation is commonly written as follows (Bunn et al., 2011):

Here, $e(p)$ is the Dirichlet Energy Density at a point $p$. The sum of the areas of all points $p$ (however small) on a surface is equal to the total area of the surface. Flat planes have DNE values of 0 . A higher DNE value therefore expresses the elements complexity and the "sharpness" of a surface (Bunn et al., 2011).

The R package "molaR" (Pampush et al., 2016), used here, requires preparation of the meshes prior to DNE calculation. For this, the platform area was isolated in MeshLab, in the same way that it was measured. To ensure consistency of DNE calculation, all meshes were simplified to 10000 faces (Spradley et al., 2017) using Quadric Edge Collapse Decimation in MeshLab. They were then rescaled so that each platform area equaled $0.1 \mathrm{~mm}^{2}$ to ensure comparable resolution of detail in each element's platform. If not resized, a small $\mathrm{P}_{1}$ element would have more faces per $\mathrm{mm}^{2}$ and, therefore, a higher resolution than a large element with the same number of faces.

292 Meshes were then smoothed in Avizo using the Avizo smoothing function with lambda $=0.6$ and 29325 iterations.

294 Twenty to thirty smoothing iterations, a conservative amount when compared to other 295 approaches (Bunn et al., 2011; Winchester et al., 2014; Spradley et al., 2017), are recommended 296 because they eliminate scanning noise while capturing fine-scale features and avoiding the 297 creation of artificial dimples that can be caused by oversmoothing (Spradley et al., 2017). 298 Different numbers of iterations $(5,10,15,20,25,30,40,50,60,70,80,90$, and 100) were tested 299 on a singular specimen of M. communisti to determine the impact of the number of smoothing 300 iterations (Figure 5). 


\section{Impact of smoothing iterations}

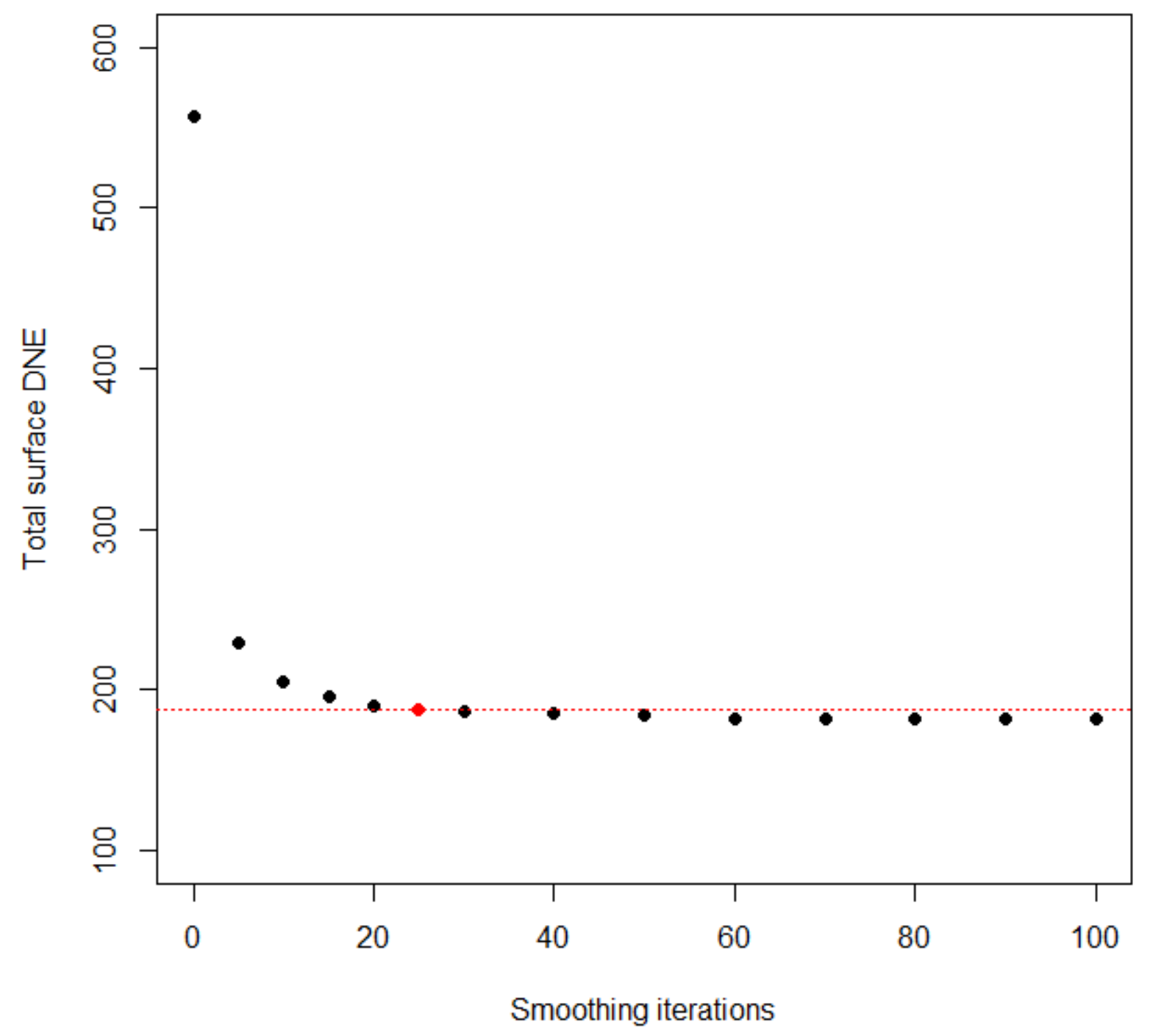

Figure 5: The impact of different numbers of smoothing iterations on DNE values measured for the platform of the $\mathrm{P}_{1}$ element NA37_A_02_GS5 (M. communisti). The red dot indicates 25 smoothing iterations.

The meshes were then resaved in MeshLab to avoid errors when calculating the DNE in R Software. They were imported into R Software as binary ply files, where they were cleaned and where the total surface DNE was calculated using the R package "molaR" (Pampush et al., 2016) with an included boundary exclusion criterion (BoundaryDiscard="vertex"), as advised by Spradley et al. (2017). The total surface DNE is the mean of all DNE values for individual faces of a surface (Pampush et al., 2016). Mean, median and variance of the DNE were calculated for each growth stage and species with R Software (R Core Team, 2021). 
312 Reduced major axis regression (RMA) was again used to examine the relationship between DNE 313 and the length of the platform, as well as the log-transformed platform area in both species.

314 Growth stage 5 was chosen for further analysis, because sufficient numbers of specimens of this 315 growth stage were available (Table 1). Growth stage 5, representing adults, also allows for 316 interpretations of the diet.

\section{Results}

\section{Growth allometry}

320 Metapolygnathus communisti

321 Regression analysis of $\mathrm{P}_{1}$ elements of $M$. communisti shows that both sets of variables (the length 322 of the platform and the length of the element, as well as the log-transformed platform area and 323 the length of the elements) are correlated (Figure 6A-C). The regression slopes of the length of 324 the element over that of the platform, as well as the regression slope of the length of the element 325 over the log-transformed area of the platform, differed significantly from one, i.e. from isometric 326 growth $(\mathrm{p}<0.000001$; Figure $6 \mathrm{~B}, \mathrm{C})$. Although the long side of the element platform is also the 327 concave one in most cases, there are differences between the two ways the platform area was 328 measured. This is reflected in the slope coefficients deviating slightly from each other (Figure $3296 \mathrm{~A})$. 
Metapolygnathus communisti
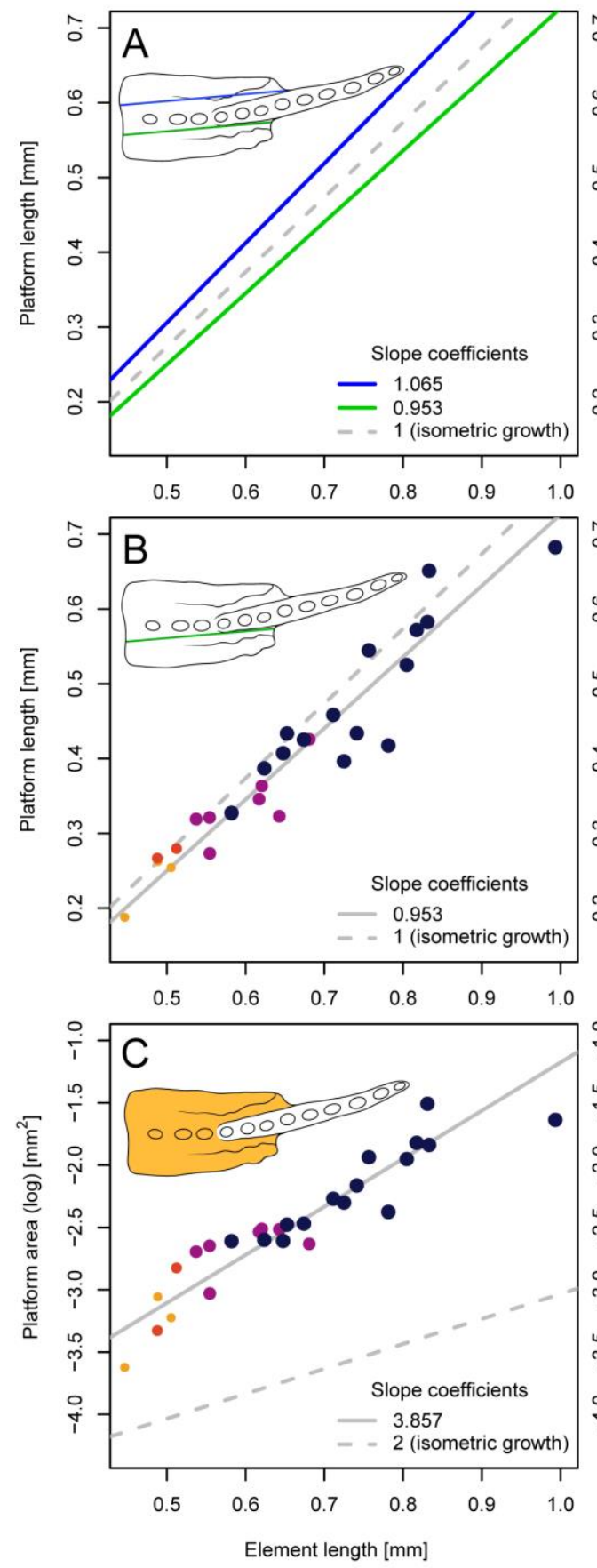

Epigondolella rigoi
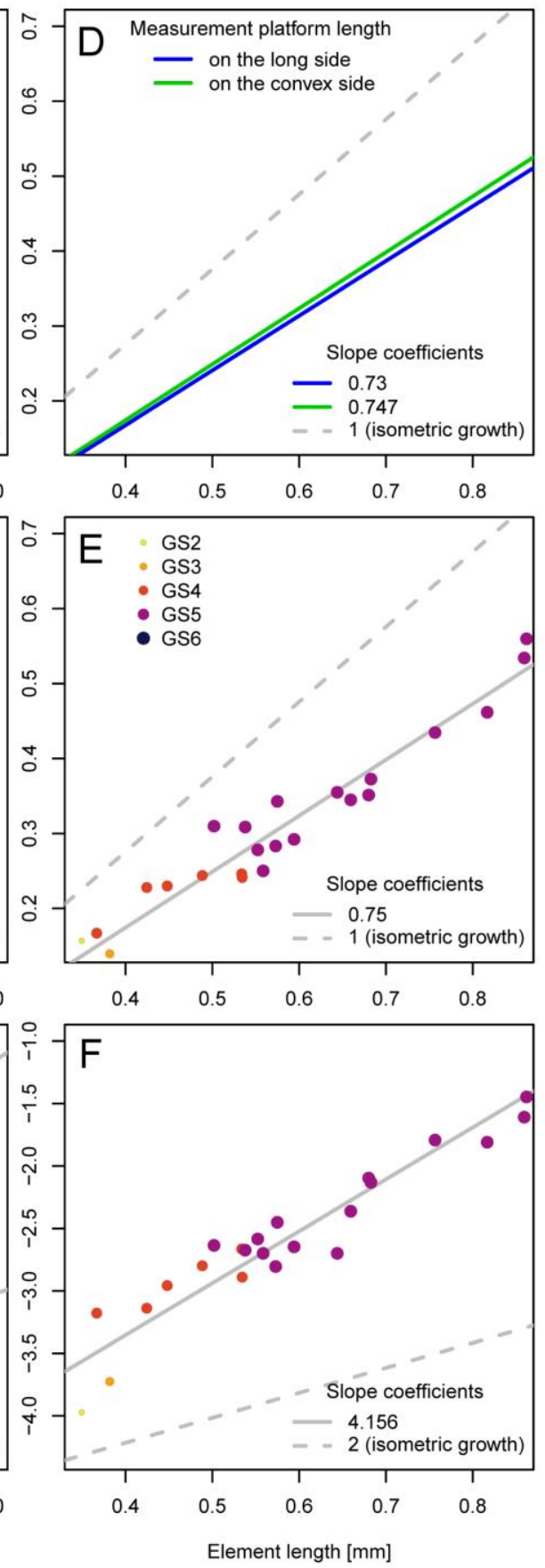
Figure 6. Allometric growth of $M$. communisti $(\mathrm{n}=27)$ and E. rigoi $(\mathrm{n}=23)$; each dot represent an element and the colours are related to the growth stage. A. Platform length over element length for M. communisti; comparison of long and convex platform length. B. Platform length over element length for $M$. communisti; convex platform length only. C. Platform area over element length for M. communisti. D. Platform length over element length for E. rigoi; comparison of long and convex platform length. E. Platform length over element length for E. rigoi; convex platform length only. F. Platform area over element length for E. rigoi.

Slope coefficients for the platform length over element length were 0.95 and 1.06 (length of platform measured on the convex and on the long side, respectively). Both values are similar to the isometric value of one, which indicates proportional growth. The slope coefficient for the log-transformed platform area was 3.86, which is greater than the isometric value of two, indicating positive allometry. The platform area grew at a faster rate than the element length (Figure 6C).

\section{Epigondolella rigoi}

In this species, both sets of variables (the length of the platform and the length of the element, as well as the log transformed platform area and the length of the elements) are also correlated (Figure 6D-F). The regression slopes of the length of the element over that of the platform, as well as the regression slope of the length of the element over the log-transformed area of the platform, differed significantly from zero $(\mathrm{p}<0.000001)$. Differences between the two ways the platform length was measured were barely visible in this species, because the long and the convex side of the platform describe the same side in almost all cases (Figure 6D). Slope coefficients for the platform length were 0.75 and 0.73 (length of platform measured on the convex and on the long side, respectively). These values are smaller than the isometric value of one, which indicates negative allometry. Here, the platform length grew at a lower rate than the element length. Slope coefficients for the platform area was 4.16, which is greater than the isometric value of two, indicating positive allometry (Figure 6F).

\section{Comparison of growth allometry in different species}

The hypothesis of molar-like function of $\mathrm{P}_{1}$ elements could not be rejected based on positive growth allometry of the platform area in both species. In M. communisti, Idiognathodus sp. and Gnathodus bilineatus, slope coefficients of the platform length close or slightly greater to the isometric value one (Idiognathodus sp.: 1.089; Purnell, 1993, 1994; Gnathodus bilineatus: 1.167; Purnell, 1994) indicate near isometric growth or slight positive allometric growth in the species. Platform length and element length grew at similar rates (Figure 7A). 


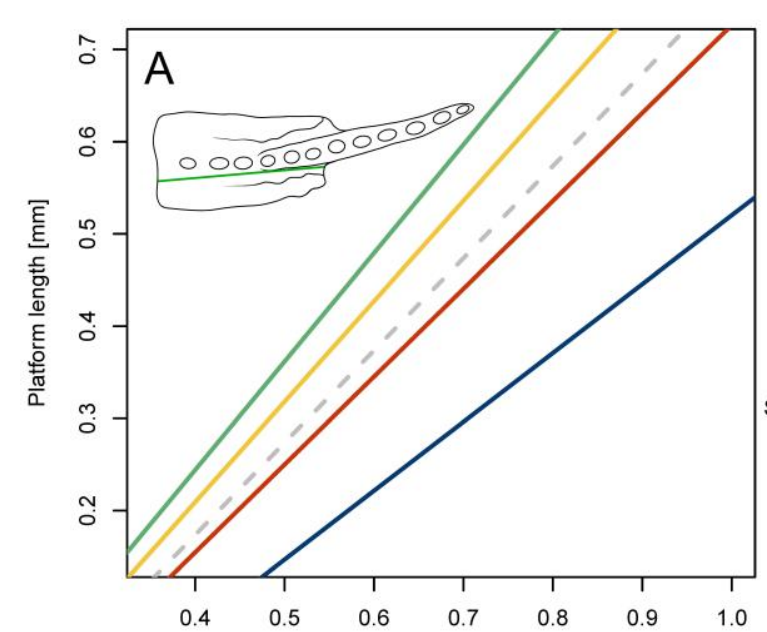

$$
\begin{aligned}
& \text { - Gnathodus bilineatus Purnell (1994) } \\
& \text { - Idiognathodus Purnell }(1993,1994) \\
& \text { - Epigondolella rigoi } \\
& \text { Metapolygnathus communisti }
\end{aligned}
$$$$
\text { - - Isometric growth }
$$

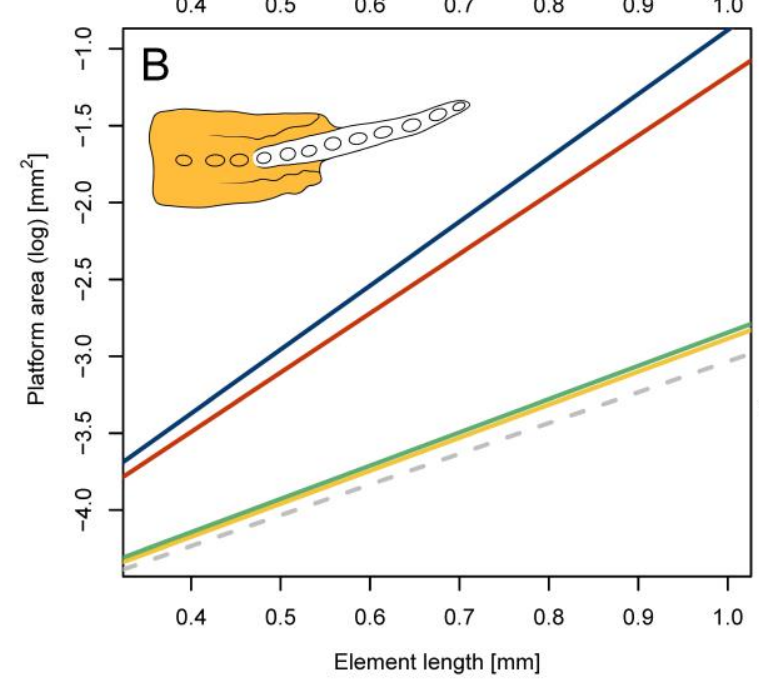

Slope coefficients

$-2.164$

- 2.149

$-3.857$

Figure 7. Comparison of the allometric growth Gnathodus bilineatus (Purnell, 1994), Idiognathodus sp. (Purnell, 1993, 1994), Epigondolella rigoi and Metapolygnathus communisti. A. Platform length over element length. Platform length in $M$. communisti and E. rigoi was measured on the convex side. B. Platform area over element length.

In E. rigoi, the negative allometry of the platform length did not follow the same growth pattern as the other species. Its platform elongated at a slightly slower rate than the length of the element (Figure 7A). atform areas in all four species showed positive allometry over element length, but at different rates. Idiognathodus sp. and Gnathodus bilineatus had the lowest slope coefficients of 2.149 and 2.164, respectively (Purnell, 1993). The slope coefficients in M. communisti and E. rigoi were 
considerably higher (Figure 7B). This may be explained by the fact that the platform area of Idiognathodus sp. was calculated as a two-dimensional surface, based on the platform's outline, and the platform area of Gnathodus bilineatus was approximated with the calculation of an ellipse with the platform's dimensions (Purnell, 1994). In contrast, platform areas of $M$. communisti and E. rigoi were in this study calculated based on three dimensional meshes.

\section{DNE}

\section{DNE through ontogeny}

Distributions of DNE values over element platforms are shown in Figure 8 and Figure 9. In both species, ontogenetically younger growth stages were represented by fewer specimens (Table 1), which made observations of these stages less conclusive. Nevertheless, in both M. communisti and E. rigoi, DNE values increased consistently with the element length (Figure 10A), as well as with the platform area (Figure 10B). No shifts in the growth trajectory of DNE were observed.

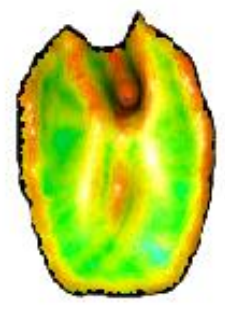

GS3

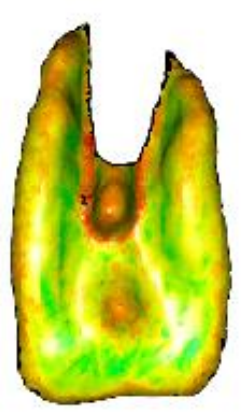

GS4

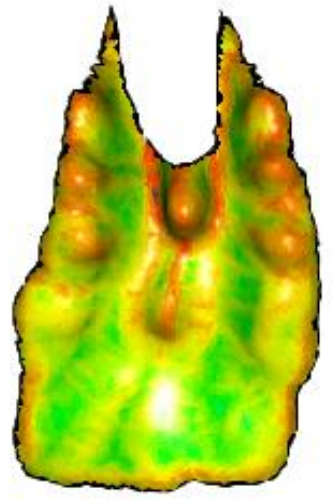

GS5

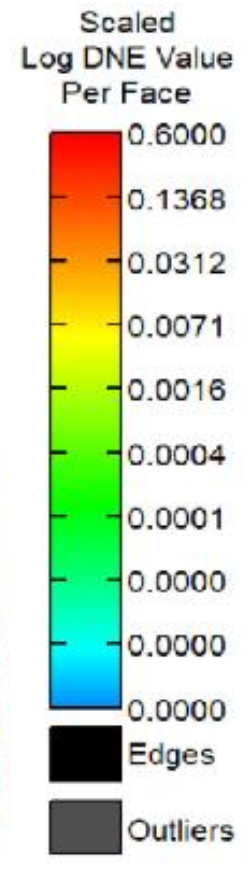

GS6

Figure 8: Log-transformed DNE values across growth stages GS3 to GS6 of Metapolygnathus communisti. 


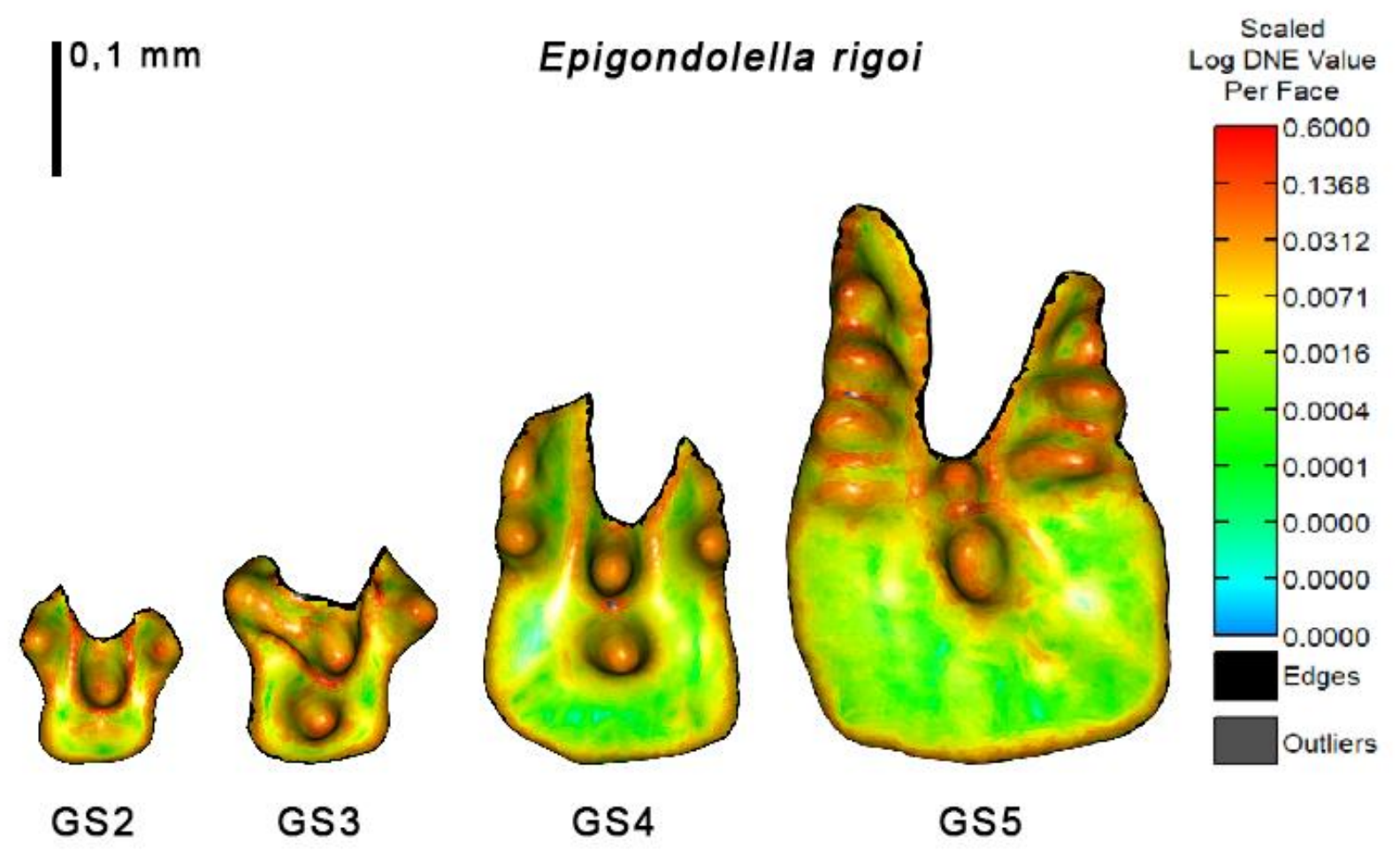

Figure 9: Log-transformed DNE values across growth stages GS2 to GS5 of Epigondolella rigoi.

The hypothesis that the dietary niches of both species, assessed using DNE as a proxy, remained the same throughout ontogeny could not, therefore, be rejected.

Regression analysis of $\mathrm{P}_{1}$ elements of $M$. communisti showed that element length, as well as platform area, are correlated with $\mathrm{DNE}\left(\mathrm{R}^{2}=0.52\right.$ and 0.61 , respectively). Regression slopes of the DNE values over element length and the log-transformed platform area differed significantly from one $(p<0.0001)$. The slope coefficients are 290.6725 and 75.41139 for element length and platform area, respectively (Figure 10A-B). area, are correlated with DNE $\left(\mathrm{R}^{2}=0.32\right.$ and 0.43 respectively). Regression slopes of DNE over element length and the log-transformed platform differed significantly from one $(\mathrm{p}<0.001)$. Slope coefficients were 395.6475 and 92.75222 for element length and platform area, respectively (Figure 10A-B).

\section{Comparison of DNE values in adult elements}

412 For the comparison of DNE values between $\mathrm{P}_{1}$ element platforms of $M$. communisti and E. rigoi, growth stage 5 is of particular interest, because both species have enough specimens of this stage 
415 conodonts which makes their DNE values suitable for comparisons outside of conodonts. It 416 needs to be remarked that the classification of growth stage 5 as "adult" does not consider 417 biology, but the morphological maturity of the elements (Mazza \& Martínez-Pérez, 2015).

418 As with the other growth stages, specimens of growth stage 5 of $E$. rigoi showed higher DNE 419 values than specimens of growth stage 5 of $M$. communisti, though there was some overlap 420 (Figure 10C). The difference in DNE values between the two species appears big enough to 421 reject the hypothesis that both species shared the same diet.
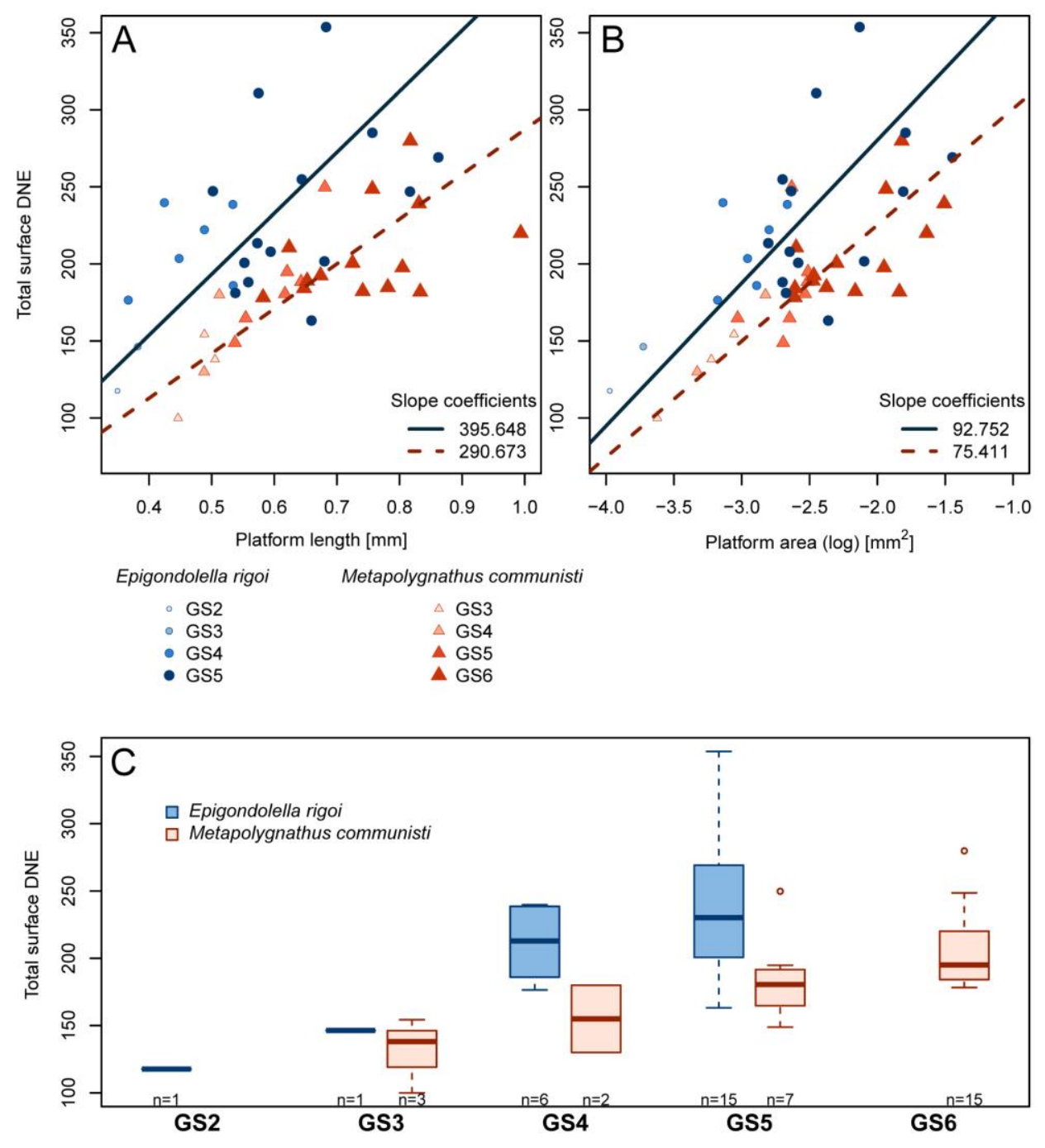
Figure 10: Regression of total surface DNE values over platform length (A), log-transformed platform area (B) in $\mathrm{P}_{1}$ elements of Epigondolella rigoi and Metapolygnathus communisti and distribution of DNE values across growth stages in both species (C).

\section{Discussion}

\section{Growth Allometry}

We were able to reject the hypothesis that platform surface area increased isometrically with respect to element length in $\mathrm{P}_{1}$ elements of Metapolygnathus communisti and Epigondolella rigoi in favour of the alternative hypothesis that the growth allometry was positive, as expected in dental organs functioning as molars. This finding supports previous finding of positive growth allometry in these organs in much older, Carboniferous, ozarkodinid taxa Gnathodus bilineatus and Idiognathodus sp. (Purnell, 1993, 1994). It is consistent with previous research on microwear (Purnell, 1995; Martínez-Pérez et al., 2014b), enamel-like ultrastructure of conodont lamellar crown tissue (Purnell, Donoghue \& Aldridge, 2000), and finite element analysis (Jones et al., 2012a).

The calculation of the platform area in three dimensions, as opposed to two dimensional approximation based on platform outline or platform dimensions (Purnell, 1994), yields more exact measurement of the area. Furthermore, measurements based on pictures suffer from distortions resulting from projecting on a plane, where differences in levelling the photographed specimens might affect the results. The effect of 3D measurements of the platform is a higher slope coefficient, meaning a more strongly positive allometry of the platform (Figure 7B).

The decision what to include in the platform for allometric analysis is worth discussing, because it is somewhat subjective. In this work, we decided to include the cusp and all carinal nodes posterior to it, because, in many cases, the cusp marked a notable transition between sharper denticles of the blade and flatter nodes on the platform. This resulted in different numbers of posterior nodes in $M$. communisti, because, in this species, the number of posterior nodes differs between growth stages (Mazza, Rigo \& Gullo, 2012; Mazza \& Martínez-Pérez, 2015). This variation has a greater effect in 3D measurements than it would in 2D. In E. rigoi the number of posterior nodes stays the same (Mazza, Rigo \& Gullo, 2012).

\section{Comparison of DNE values in adult elements}

Differences in DNE values between $M$. communisti and E. rigoi are great enough to merit a careful

\section{Dirichlet Normal Energy}

\section{Ontogenetic development of DNE}

In M. communisti, as well as in E. rigoi, DNE values increased linearly with body size, where element length was used as a proxy for body size (Zhang et al., 2018; Ginot \& Goudemand, 2019). This does not contradict the possible presence of a larval stage, during which conodonts had a different method of feeding (Shirley et al., 2018), because all specimens that are considered here were more mature. suggestion of different diets between the two species. More DNE analyses on conodonts are needed to understand the scope of DNE values in conodonts and to confidently suggest that a 
certain discrepancy between DNE values of different species reflects different dietary niches. Here, the only reference values were those available for exclusively terrestrial mammals, and mostly for primates.

DNE values of growth stage 5 specimens of $M$. communisti and E. rigoi are similar to those reported for insectivores or folivores in the case of E. rigoi and for folivores or omnivores in the case of $M$. communisti, had these DNE values been observed in primates (Bunn et al., 2011; Winchester et al., 2014). Within the range of DNE values observed in primates, these values are relatively high. Though these dietary classifications are not applicable to conodonts, they may offer a general reference point for the methods of breaking down different food types. Insectivores rely on sharp cusps to apply maximal force on a small surface, in order to pierce hard insect chitin, folivores also use steeply sloped cusps to shear tough cellulose-rich leaves. (Lucas, 1979; Strait, 1997).

It is possible that conodont element platforms adapted to break down food types with similar properties. It has been suggested that conodonts may have punctured arthropod larvae (Dzik, 2021), which would be consistent with the DNE values observed in M. communisti.

\section{Problems in DNE analysis of conodont elements}

There are several challenges researchers face when working with DNE in conodonts. As DNE is a comparatively new tool, reference values and understanding of variability (e.g. intraspecific, ontogenetic, resulting from preservation) is limited. So far, DNE research has focused on gnathostomes, whose tooth function is, in large part, reliant on jaws acting as levers. This necessitates that the comparisons that are drawn here between conodont elements and primate molars must be viewed as extremely hypothetical. Marine environment, evolutionary distance and the lack of jaws in conodonts make it likely that tooth function is not completely analogous between the two.

Typical applications of DNE do not take into account ontogenetic development of conodonts, because, contrary to mammalian molars, in conodonts the number of denticles in $\mathrm{P}_{1}$ element platforms increases during ontogenetic growth. This plays into the recurring problem of what to include in the conodont platform, which also has an impact on DNE. This was especially problematic in $M$. communisti, because here, in addition to denticles on the platform margins increasing in number over ontogenetic growth, the number of carinal nodes posterior to the cusp varies between growth stages.

A consistent protocol of mesh preparation prior to DNE calculation is also needed. Especially the number of smoothing iterations varies in current literature and this can have impact on DNE results (Spradley et al., 2017). This is important, because comparisons are most conclusive when drawn between data with comparable preparation. We second the recommendations by Spradley et al. (2017): a conservative number of smoothing iterations (20-30) using non-Laplace-based smoothing operators, such as that implemented in Avizo, and mesh simplification to a fixed 504

\section{Conclusions}


We tested the hypothesis that conodont $\mathrm{P}_{1}$ elements performed molar-like function by analysing the growth allometry of platform surface area versus length, following the protocol by Purnell (1993, 1994), but in 3D meshes rather than on 2D projections of platforms. We further used slopes of this allometric relationships to test the hypothesis that conodonts occupying the same environments shared the same trophic positions. We applied the test to $3 \mathrm{D}$ surfaces of $\mathrm{P}_{1}$ elements of the ozarkodinid conodont species Metapolygnathus communisti and Epigondolella rigoi from the Upper Triassic section Pizzo Mondello in western Sicily, Italy. Platform length grew isometrically with respect to element length, whereas log-transformed platform area showed positive allometry with respect to element length, with slopes equal 3.86 in $M$. communisti and 4.16 in E. rigoi. These values are substantially higher than those reported for Carboniferous conodonts Idiognathodus sp. and Gnathodus bilineatus (Purnell, 1993), but this may reflect a more precise measurement of surface area in 3D models compared to 2D projections used in previous studies. Thus, it is not possible to compare these values directly, but we conclude that stronger positive allometry of platform area in E. rigoi indicates higher metabolic needs and might be a proxy for a higher trophic level compared to M. communisti. We also applied dental topographic analysis using Dirichlet Normal Energy (DNE) to the platforms in order to test the hypotheses that the diets of $M$. communisti and E. rigoi did not change during ontogenetic growth and that they occupied the same dietary niches. Surface DNE values increased linearly in function of element length and log-transformed platform area, indicating no ontogenetic changes. Specimens of the adult growth stage of E. rigoi showed higher DNE values than specimens of the same growth stage in $M$. communisti, consistent with stronger positive allometry of platform surface and with a higher demand for energy in this species. Based on DNE values available for primates, those of the adult growth stages were similar to those reported for insectivores or folivores in the case of E. rigoi and for folivores or omnivores in the case of $M$. communisti. Previous studies applying morphological and ultrastructural proxies for the dietary position of conodonts addressed mostly stratigraphically older conodont taxa, but our results indicate that Late Triassic species occupied the predator/scavenger niche in spite of the highly developed diversity of gnathostomes in this niche. We also show that within this broad niche, co-occurring taxa differed in their diets, which supports trophic diversification as an important driver of the remarkable disparity of their elements.

\section{Acknowledgements}

We thank Bryan Shirley for support in using Aviso and Wyatt Petryshen for advice on cleaning and saving meshes. We also thank Nicolas Goudemand for supporting the project. PG was supported by Visiting Scholarship awarded by Friedrich-Alexander-Universität ErlangenNürnberg. EJ was supported by Deutsche Forschungsgemeinschaft (project no JA 2718/3-1). MR was supported by DOR2054230/20 by University of Padova.

\section{References}


Alberch P, Gould SJ, Oster GF, Wake DB. 1979. Size and shape in ontogeny and phylogeny. Paleobiology 5:296-317.

Balter V, Martin JE, Tacail T, Suan G, Renaud S, Girard C. 2019. Calcium stable isotopes place Devonian conodonts as first level consumers. Geochemical Perspectives Letters 10:36-39.

Bengtson S. 1976. The structure of some Middle Cambrian conodonts, and the early evolution of conodont structure and function. Lethaia 9:185-206. DOI: 10.1111/j.1502-3931.1976.tb00966.x.

Bunn JM, Boyer DM, Lipman Y, St. Clair EM, Jernvall J, Daubechies I. 2011. Comparing Dirichlet normal surface energy of tooth crowns, a new technique of molar shape quantification for dietary

Cignoni P, Callieri M, Corsini M, Dellepiane M, Ganovelli F, Ranzuglia G. 2008. Meshlab: an opensource mesh processing tool. In: Eurographics Italian Chapter Conference. 129-136.

Donoghue PCJ. 2001a. Conodonts meet cladistics: recovering relationships and assessing the completeness of the conodont fossil record. Palaeontology 44:65-93. DOI: 10.1111/1475-

Donoghue PCJ. 2001b. Microstructural variation in conodont enamel is a functional adaptation. 10.1098/rspb.2001.1728.

Donoghue PCJ, Purnell MA. 1999a. Mammal-like occlusion in conodonts. Paleobiology 25:58-74. 254. DOI: 10.1130/0091-7613(1999)027<0251:GFATCF>2.3.CO;2.

Donoghue PCJ, Purnell MA, Aldridge RJ. 1998. Conodont anatomy, chordate phylogeny and vertebrate classification. Lethaia 31:211-219. DOI: 10.1111/j.1502-3931.1998.tb00509.x. 

10.1016/j.earscirev.2020.103176.

Dzik J. 1991. Evolution of oral apparatuses in the conodont chordates. Acta Palaeontologica Polonica $36: 265-323$.

Dzik J. 2008. Evolution of morphogenesis in 360-million-year-old conodont chordates calibrated in days. Evolution \& Development 10:769-777. DOI: 10.1111/j.1525-142X.2008.00291.x.

Dzik J. 2015. Evolutionary roots of the conodonts with increased number of elements in the apparatus. Earth and Environmental Science Transactions of the Royal Society of Edinburgh 106:29-53.

Dzik J. 2021. Protaspis larva of an aglaspidid-like arthropod from the Ordovician of Siberia and its habitat. Arthropod Structure \& Development 61:101026. DOI: 10.1016/j.asd.2020.101026.

Epstein AG, Epstein JB, Harris LD. 1977. Conodont color alteration: an index to organic metamorphism. United States Geological Survey Professional Paper 995:1-27.

Foote M, Sepkoski JJ. 1999. Absolute measures of the completeness of the fossil record. Nature 398:415-

585 417. DOI: $10.1038 / 18872$.

Gabbott SE, Aldridge RJ, Theron JN. 1995. A giant conodont with preserved muscle tissue from the Upper Ordovician of South Africa. Nature 374:800-803. DOI: 10.1038/374800a0.

Ginot S, Goudemand N. 2019. Conodont size, trophic level, and the evolution of platform elements. Paleobiology 45:458-468. DOI: 10.1017/pab.2019.19.

Ginot S, Goudemand N. 2020. Global climate changes account for the main trends of conodont diversity but not for their final demise. Global and Planetary Change 195:103325. DOI: 10.1016/j.gloplacha.2020.103325.

Gould SJ. 1966. Allometry and size in ontogeny and phylogeny. Biological Reviews 41:587-638. DOI: 10.1111/j.1469-185X.1966.tb01624.x.

Guenser P, Souquet L, Dolédec S, Mazza M, Rigo M, Goudemand N. 2019. Deciphering the roles of environment and development in the evolution of a Late Triassic assemblage of conodont elements. Paleobiology 45:440-457. DOI: 10.1017/pab.2019.14. 
Hayashi S. 1968. The Permian Conodonts in Chert of the Adoyama Formation, Ashio Mountains, Central Japan. Earth Science 2:63-77.

Jones D, Evans AR, Rayfield EJ, Siu KKW, Donoghue PCJ. 2012a. Testing microstructural adaptation in the earliest dental tools. Biology Letters 8:952-955. DOI: 10.1098/rsbl.2012.0487.

601 Jones D, Evans AR, Siu KKW, Rayfield EJ, Donoghue PCJ. 2012b. The sharpest tools in the box?

602 Quantitative analysis of conodont element functional morphology. Proceedings of the Royal

603 Society B: Biological Sciences 279:2849-2854. DOI: 10.1098/rspb.2012.0147.

604 Klingenberg CP. 1996. Multivariate Allometry. In: Marcus LF, Corti M, Loy A, Naylor GJP, Slice DE eds. Advances in Morphometrics. Boston, MA: Springer US, 23-49. DOI: 10.1007/978-1-4757-

Klug C, Kröger B, Kiessling W, Mullins GL, Servais T, Fryda J, Korn D, Turner S. 2010. The Devonian 9083-2_3. nekton revolution. Lethaia 43:465-477. DOI: 10.1111/j.1502-3931.2009.00206.x.

Lucas PW. 1979. The Dental-Dietary Adaptations of Mammals. Neues Jahrbuch für Geologie und Paläontologie Monatshefte 8:486-512.

Martínez-Pérez C, Cascales-Miñana B, Plasencia P, Botella H. 2015. Exploring the major depletions of conodont diversity during the Triassic. Historical Biology 27:503-507. DOI: 10.1080/08912963.2014.890192.

617 Martínez-Pérez C, Plasencia P, Jones D, Kolar-Jurkovšek T, Sha J, Botella H, Donoghue PCJ. 2014 b. There is no general model for occlusal kinematics in conodonts. Lethaia 47:547-555. DOI: 10.1111/let.12080. of conodont feeding ecology. Geology 44:247-250. DOI: 10.1130/G37547.1. 
Martínez-Pérez C, Rayfield EJ, Purnell MA, Donoghue PCJ. 2014c. Finite element, occlusal, microwear and microstructural analyses indicate that conodont microstructure is adapted to dental function. Palaeontology 57:1059-1066. DOI: 10.1111/pala.12102.

Mazza M, Cau A, Rigo M. 2012. Application of numerical cladistic analyses to the Carnian-Norian

Mazza M, Furin S, Spötl C, Rigo M. 2010. Generic turnovers of Carnian/Norian conodonts: Climatic control or competition? Palaeogeography, Palaeoclimatology, Palaeoecology 290:120-137.

Mazza M, Martínez-Pérez C. 2015. Unravelling conodont (Conodonta) ontogenetic processes in the Late Triassic through growth series reconstructions and X-ray microtomography. Bollettino della

Mazza M, Nicora A, Rigo M. 2018. Metapolygnathus parvus Kozur, 1972 (Conodonta): a potential primary marker for the Norian GSSP (Upper Triassic). Bollettino della Società Paleontologica Italiana. DOI: 10.4435/BSPI.2018.06.

Mazza M, Rigo M, Gullo M. 2012. Taxonomy and biostratigraphic record of the Upper Triassic conodonts of the Pizzo Mondello section (western Sicily, Italy), GSSP candidate for the base of the Norian. Rivista Italiana di Paleontologia e Stratigrafia 118:85-130.

Nicoll RS. 1987. Form and function of the Pa element in the conodont animal. In: Aldridge RJ ed. Palaeobiology of conodonts. Chichester: Ellis Horwood, 77-90. (Sicani Mountains, Sicily) and its bearing for the definition of the GSSP of the Norian Stage. Albertiana 36:102-129.

Noyan ÖF, Kozur HW. 2007. Revision of the late Carnian-early Norian conodonts from the Stefanion section (Argolis, Greece) and their palaeobiogeographic implications. Neues Jahrbuch für

\section{.} Geologie und Paläontologie-Abhandlungen 245:159-178. 
Pampush JD, Winchester JM, Morse PE, Vining AQ, Boyer DM, Kay RF. 2016. Introducing molaR: a Surfaces). Journal of Mammalian Evolution 23:397-412. DOI: 10.1007/s10914-016-9326-0.

Petryshen W, Henderson CM, De Baets K, Jarochowska E. 2020. Evidence of parallel evolution in the

Purnell MA. 1994. Skeletal ontogeny and feeding mechanisms in conodonts. Lethaia 27:129-138. DOI: 10.1111/j.1502-3931.1994.tb01567.x.

Purnell MA. 1995. Microwear on conodont elements and macrophagy in the first vertebrates. Nature 374:798-800. DOI: 10.1038/374798a0.

Purnell MA, von Bitter PH. 1992. Blade-shaped conodont elements functioned as cutting teeth. Nature 359:629-631. DOI: 10.1038/359629a0.

Purnell MA, Donoghue PCJ, Aldridge RJ. 2000. Orientation and anatomical notation in conodonts. Journal of Paleontology 74:113-122. DOI: 10.1017/S0022336000031292. Statistical Computing, Vienna, Austria. 16:76-85. DOI: 10.1007/BF03041668.

Scott HW. 1934. The zoological relationships of the conodonts. Journal of Paleontology 8:448-455. models of growth dynamics in conodonts with high-resolution imaging. Proceedings of the Royal Society B: Biological Sciences 285:20181614. DOI: 10.1098/rspb.2018.1614. 
672 Spradley JP, Pampush JD, Morse PE, Kay RF. 2017. Smooth operator: The effects of different 3D mesh 673 retriangulation protocols on the computation of Dirichlet normal energy. American Journal of $674 \quad$ Physical Anthropology 163:94-109. DOI: 10.1002/ajpa.23188.

675 Strait SG. 1997. Tooth use and the physical properties of food. Evolutionary Anthropology: Issues, News, 676 and Reviews 5:199-211. DOI: 10.1002/(SICI)1520-6505(1997)5:6<199::AID-

$677 \quad$ EVAN2>3.0.CO;2-8.

678 Warton DI, Duursma RA, Falster DS, Taskinen S. 2012. smatr 3- an R package for estimation and 679 inference about allometric lines. Methods in Ecology and Evolution 3:257-259. DOI:

$680 \quad$ 10.1111/j.2041-210X.2011.00153.x.

681 Winchester JM, Boyer DM, St. Clair EM, Gosselin-Ildari AD, Cooke SB, Ledogar JA. 2014. Dental 682 topography of platyrrhines and prosimians: Convergence and contrasts. American Journal of 683 Physical Anthropology 153:29-44. DOI: 10.1002/ajpa.22398.

684 Zhang S, Aldridge RJ, Donoghue PCJ. 1997. An Early Triassic conodont with periodic growth? J. $685 \quad$ Micropalaeontol. 16:65-72. DOI: 10.1144/jm.16.1.65.

686 Zhang ZT, Sun YD, Wignall PB, Fu JL, Li HX, Wang MY, Lai XL. 2018. Conodont size reduction and 687 diversity losses during the Carnian Humid Episode in SW China. Journal of the Geological $688 \quad$ Society $175: 1027-1031$. 